\title{
Views on Learning Difficulties in Basic Sciences by Mainland Chinese Students
}

\author{
Ken Chan \\ Science Consultant, Australia
}

\begin{abstract}
Science programs at Western higher education institutions are popular with mainland Chinese students. My teaching experience in Chinese classes suggests significant challenges for China-raised students in gaining deep appreciation and understanding of the principles of pure science, which differs from applied science in motivation and skills. The learning difficulties can be traced to students' early education and cultural background. Science further communicates in a different style to other forms of English, adding complexity to writing and reading science texts. The information provided here could benefit future development of new course structures and teaching style in basic sciences, which is expected to generate a better appreciation of Western basic science philosophy by China-raised learners who in turn will gain a more rewarding learning experience.
\end{abstract}

Keywords: basic/pure science, cultural background, early education, memorization, scientific English, self-directed learning

I have been fortunate to be invited to teach biology and scientific English intermittently in China over the years. Although science programs are popular with Chinese international students (National Science Board, 2018), biology is generally not a preferred academic degree among domestic students. Coming from a pure (also known as "basic") science background under the Australian higher education system, my primary role was to provide inspiration for quality pure biology learning. Many of my students were enthused by the class exposure and expressed a genuine desire to acquire/continue their basic science education abroad as international students. However, my experience shows that China-raised 
students would struggle in Western basic science programs. For example, curiosity and an inquiring mind are prerequisites to learning basic science, but I felt compelled to instigate these qualities while teaching biological material and to find ways to inject a deep appreciation and understanding of basic science principles. To my knowledge, learning of pure science by mainland Chinese students has not been addressed in Western higher education.

In reflecting on my experience with teaching and interacting with undergraduate and postgraduate Chinese students, it is important in the context of Western science education to first distinguish basic science from applied science. Basic science is search for understanding of natural phenomena without expectations of practical applications. Applied science uses the knowledge base provided by basic science research to develop technologies for human practical purposes. In this way, pure and applied scientists differ in their motivation and skills. The drive to generate new knowledge and ideas about the natural world in basic science leads to skills in investigative receptiveness that demands independent inquiry, well-planned experiments, and evidence-based arguments. Higher education in Australia typically emphasizes the importance of such basic science values even in applied science degrees that ultimately focus on practical skills in scientific procedures and techniques. This is because a viral vaccine, for example, cannot be developed without first understanding the structure and function of viral protein and the human immune system. China is believed to lack a basic science culture and its science development is traditionally driven by pragmatic actions (Wan et al., 2011). Its educational and financial support is tailored toward applied skills for practical and economic reasons. China has a rapidly growing reputation in the sciences, including life sciences, but is heavily biased toward applied fields such as materials science and biotechnology (O’Meara, 2019).

\section{LEARNING BACKGROUND}

My children experienced first-hand the education culture of China when they attended a primary school at Chongqing municipality in 2005. The school upheld a teacher-centered culture in which deference for the teacher accompanied by classroom silence was practiced. The teacher would unhesitatingly strike a student's desk with a ruler if they felt the student's attention waivered. Teaching and learning tended to focus on content-packed information delivery with much rote memorization and recitation of texts, a method that continues throughout the six years of secondary education because it suits examination-oriented assessment. It is a practice that still occurs in many schools in China today (e.g., Poole, 2016; Rublik, 2018). Although a selection of science subjects is taught at secondary school, science projects and extracurricular science activities are limited. A lack of hands-on activities, observation and demonstration in classrooms, coupled with a teacher-oriented approach that allays student development of questioning and reasoning, tends to undermine student inquisitiveness and originality and consequently basic science learning. 
Behavior of my undergraduate biology students in China is suggestive of under-preparation for deep and meaningful learning of basic science at university. There is strong reliance on memorization of material. Students typically regurgitate the exact wordings of learnt definitions when asked to explain a biological concept. They are often confused when prompted to expand and apply to different situations. Chinese students are said to employ repetition learning as a means of gaining deep understanding over time (Kember, 2016), but the strategy could obscure the distinction between surface and deep learning. Repetition learning requires diligence and persistence which are admirable qualities of the Chinese people. Chinese students not only study for longer hours than their Australian counterparts; many believe effort is more reliable in achieving success than academic ability. In one advanced-level biology course (evolutionary biology) I delivered in China, many students claimed they often studied more for this subject than all other Chinese subjects combined. They articulated that English language incompetency was one factor, but the adjustment required in dealing with high-level critical and analytical thinking was especially challenging because the process cannot be learned through memorization. A common student opinion is that secondary school study is more arduous than that at university. Students were somewhat astonished at the higher learning expectations in my courses and that the learning methods that worked for them in secondary school were largely ineffective.

\section{ACADEMIC CHALLENGES IN BASIC SCIENCES ABROAD}

So how do/would Chinese international students fare at Western higher education institutions? Studies suggest they regularly match or outdo their Western counterparts in academic performance (Kember, 2016); however, the types of courses in which mainland Chinese students excelled in are primarily mathematics and nonpure sciences such as the arts, business, or technology (an applied science). Data specific to pure science performance (other than mathematics) are lacking in the literature, but in Australia where almost $40 \%$ of tertiary international students are from mainland China (Department of Education and Training, 2019), there is some suggestion that China-raised students underperform in biology-related courses compared to domestic students (e.g., Mann et al., 2010). Incompetence in the English language is often cited as one primary factor limiting academic success for international students (e.g., Ren \& Hagedorn, 2012), but this element is less crucial in the natural sciences (Light et al., 1987). Some of the English-proficient students in my biology courses in China performed dismally, while those possessing less competent English performed considerably better. Undoubtedly cultural background and acculturation are central to pure science learning in Western institutions.

According to a study by Bone and Reid (2011), early exposure to deep learning in biology is more important than preuniversity learning. Since early education in China does not promote qualities such as creative thinking and problem solving (Dello-Iacovo, 2009; Ma \& Rapee, 2015; Niu \& Sternberg, 2003; Salili, 1996), a sudden shift to high-level learning in basic science (e.g., hypothesis 
testing, scientific argument) can be problematic. English language-proficient China-raised students studying in Western institutions are known to perform adequately in first year subjects in which a surface learning approach is normally sufficient, but less so in the second and final years that typically require a deeper and more strategic approach (Crawford \& Wang, 2015). A possible reason is that students may find it difficult to transition from a memorization/repetition strategy to adopting different learning strategies to suit higher year levels. However, I found retaining the ingrained memorization strategy can remain positive for students as long as additional strategies are available to facilitate their adaptation efforts (e.g., learning Latin/Greek stem words to deal with biology vocabulary). Another deficiency I noticed in Chinese classes is the near-absence of group activities and oral presentations, an issue also observed by other Western authors (e.g., Holmes, 2004; Jin \& Cortazzi, 2006; Rublik 2018) and is being addressed recently at some universities ( $\mathrm{Li}$ et al., 2014). Underdeveloped listening and speaking dexterities could create difficulties in verbal participation (asking questions, delivering presentations, partaking in tutorials) in Western classes. This shortcoming should not be confused with nonparticipation in class discussions arising from language incompetency.

\section{COMMUNICATION CULTURE}

The ability to communicate one's work is a necessary skill in science, but one that has proven to be especially challenging for mainland Chinese students. "Scientific English" is a form of academic English language that deals not only with grammar and vocabulary used in science, but also with features such as writing style, accuracy, and objective interpretation of facts and findings (Chan, 2009). Fluency in proper English does not necessarily indicate command of scientific English. Many graduate students in my Chinese classes possess a good knowledge of the English vocabulary but are often unable to comprehend the inherent meaning of English biology texts. The same English-competent students also commit recurring errors in their written work despite repeated correction. Typical examples include:

- a lack of clarity caused by unclear and indirect writing;

- a lack of consistency caused by loose text structure and planning;

- a tendency to be speculative and partial in analytical judgment;

- unnecessary repetition of same information;

- insufficient description of the significance of study and study aim; and

- inaccurate and indifferent application of statistical methods in ecological research.

Although some authors suggest that scientific writing can be learned through practice (see references in Deng et al., 2019), Chinese students are so accustomed to a reader-responsible style of writing — one that leaves the reader guessing - that it may become difficult to reverse (Holmes 2004; Kaplan 1966). From extensive experience in assignment marking and scientific paper reviews, I have concluded 
that problems in reading and written communication are due primarily to differences in learning context expectations between cultures (see also Xing et al., 2008). In reading, for example, China-raised students are conditioned to memorizing texts for deep understanding, a strategy that does not work well for subjects with a heavy reading load (see also Holmes, 2004), let alone one filled with Western abstract scientific concepts. Because conclusions are drawn from observations, elements of the scientific method of investigation such as hypothesis and complete openness to empirical testing are abstract concepts that need to be well understood. Other science terms such as compare-and-contrast and causeand-effect express the type of logical progressions unfamiliar to Chinese thinking. The overall Chinese communication style is further shaped by the deep-rooted culture of balancing harmony, avoiding losing face, and respecting hierarchical and social relationships (Rublik, 2018; Valiente, 2008; Wang et al., 2015). For example, the desire to maintain social harmony results in a tendency to express personal views in an indirect or diffident way to avoid conflicts, while strong respect for the teacher's knowledge may lead to own restrained analytical judgment. Written communication is likewise guided in ways that may conflict with the requisites for scientific English.

In scientific writing, the responsibility lies with the writer, who is entrusted with conveying the message succinctly to the reader through careful organization and planning, conciseness, and with clear and effective details and arguments (Chan, 2009; Deng et al., 2019). Most students in my Chinese classes struggled with time management, study organization strategies, attention to detail, and homework tasks which were apparently uncommon. The problem can be traced to a teacher-reliant approach to learning instead of using student initiative to organize own learning in the best possible way. I encountered great difficulties in promoting self-directed learning while in China, as independent thinking is somewhat contrary to a teacher-centered and exam-focused approach in Chinese education. As a rule, a basic science education process exists in Western universities to guide students through increasing levels of scientific insight and abandoning classroom examinations to eventually become independent researchers. Adoption of self-directed independent learning from the beginning allows accelerated adaptation to communication and performance in basic science.

\section{CONCLUSION AND RECOMMENDATIONS}

Australian higher education is currently gripped by a coronavirus pandemic that threatens forever the way courses are structured and delivered. Students from China face tight restrictions to enter the country, and universities are switching to online teaching. More so than most other disciplines, pure science training is severely affected by the absence of face-to-face learning. A better understanding of students' educational and cultural background relevant to basic science learning will greatly benefit future development of new course structures and a teaching style that incorporates rationalization and tracking of student-centered learning. This is expected to generate a better appreciation of Western basic 
science philosophy by China-raised learners who in turn will gain a more rewarding learning experience. Issues on difficulties of Chinese students assimilating to a Western style of learning have been covered widely in the literature (e.g., Ching et al., 2017; God \& Zhang, 2019; Henze \& Zhu, 2012; Holmes, 2004; Leong, 2015; Wang et al., 2015), but very few studies were specific to the context of basic science teaching and learning. Future research is required to ensure/help students:

- hold full responsibility for self-directed learning (i.e., abandon the teacher-reliant learning approach), including thinking scientifically;

- become versed with the principles of scientific English as distinguished from conversational and even from non-science-specific academic English;

- understand scientific concepts, both concrete and abstract, before integrating the content;

- distinguish the learning demands and skills required for applied and basic sciences and their corresponding surface and deep learning expectations; and

- embrace additional learning strategies to memorization strategy as a means to accelerate deep understanding in advanced-level science courses.

\section{REFERENCES}

Bone, E. K., \& Reid, R. J. (2011). Prior learning in biology at high school does not predict performance in the first year at university. Higher Education Research \& Development, 30(6), 709-724. http://dx.doi.org/10.1080/07294360.2010. 539599

Chan, K. (2009). Scientific English: An essential guide to academic English for Chinese scientists. Tsinghua University Press.

Ching, Y., Renes, S. L., McMurrow, S., Simpson, J., \& Strange, A. T. (2017). Challenges facing Chinese international students studying in the United States. Educational Research and Reviews, 12(8), 473-482. https://doi.org/ 10.5897/ERR2016.3106

Crawford, I., \& Wang, Z. (2015). The impact of individual factors on the academic attainment of Chinese and UK students in higher education. Studies in Higher Education, 40(5), 902-920. https://doi.org/10.1080/03075079.2013.851182

Dello-Iacovo, B. (2009). Curriculum reform and 'Quality Education' in China: An overview. International Journal of Educational Development, 29, 241-249. https://doi.org/10.1016/j.ijedudev.2008.02.008

Deng, Y., Kelly, G. J., \& Xiao, L. (2019). The development of Chinese undergraduate students' competence of scientific writing in the context of an advanced organic chemistry experiment course. Chemistry Education Research and Practice, 20(1), 270-287. https://doi.org/10.1039/C8RP00171E

Department of Education and Training. (2019). 2017 Section 4 All student load. Australian Government. https://docs.education.gov.au/node/51331 
God, Y. T., \& Zhang, H. (2019). Intercultural challenges, intracultural practices: How Chinese and Australian students understand and experience intercultural communication at an Australian university. Higher Education, 78(2), 305-322. https://doi.org/10.1007/s10734-018-0344-0

Henze, J., \& Zhu, J. (2012). Current research on Chinese students studying abroad. Research in Comparative and International Education, 7(1), 90-104. https://doi.org/10.2304/rcie.2012.7.1.90

Holmes, P. (2004). Negotiating differences in learning and intercultural communication: Ethnic Chinese students in a New Zealand University. Business Communication Quarterly, 67, 294-307. https://doi.org/10.1177/108056990 4268141

Jin, L., \& Cortazzi, M. (2006). Changing practices in Chinese cultures of learning. Language, Culture and Curriculum, 19(1), 5-20. https://doi.org/10.1080/ 07908310608668751

Kaplan, R. (1966). Cultural thought patterns in intercultural education. Language Learning, 2, 15-27. https://doi.org/10.1111/j.1467-1770.1966.tb00804.x

Kember, D. (2016). Why do Chinese students out-perform those from the West? Do approaches to learning contribute to the explanation? Cogent Education, 3(1), 1-15. https://doi.org/10.1080/2331186x.2016.1248187

Leong, P. (2015). Coming to America: Assessing the patterns of acculturation, friendship, formation, and the academic experiences of international students at a US college. Journal of International Students, 5(4), 459-474. https:// doi.org/10.32674/jis.v5i4.408

Li, D., Remedios, L., \& Clarke, D. (2014). Chinese students' groupwork practices and experiences in China. Higher Education, 68(2), 227-241. https://doi.org/ 10.1007/s10734-013-9704-y

Light, R. L., Xu, M., \& Mossop, J. (1987). English proficiency and academic performance of international Students. Tesol Quarterly, 21(2), 251-261. https://doi.org/10.2307/3586734

Ma, C. C. E., \& Rapee, R. M. (2015). Differences in mathematical performance, creativity potential, and need for cognitive closure between Chinese and Australian students. The Journal of Creative Behavior, 49(4), 295-310. https://doi.org/10.1002/jocb.67

Mann, C., Canny, B., Lindley, J., \& Rajan, R. (2010). The influence of language family on academic performance in year 1 and 2 MBBS students. Medical Education, 44(8), 786-794. https://doi.org/10.1111/j.1365-2923.2010.03711.x

National Science Board. (2018). Science and engineering indicators 2018. Higher education in science and engineering. National Science Foundation.

Niu, W., \& Sternberg, R. J. (2003). Societal and school influences on student creativity: The case of China. Psychology in the Schools, 40(1), 103-114. https://doi.org/10.1002/pits. 10072

O'Meara, S. (2019). The materials reality of China. Nature, 567, S1-S5. https://doi.org/10.1038/d41586-019-00885-5 
Poole, A. (2016). 'Complex teaching realities' and 'deep rooted cultural traditions': Barriers to the implementation and internalisation of formative assessment in China. Cogent Education, 3(1), 1-14. https://doi.org/10.1080/2331186x. 2016.1156242

Ren, J., \& Hagedorn, L. S. (2012). International graduate students' academic performance: What are the influencing factors? Journal of International Students, 2(2), 135-143. https://doi.org/10.32674/jis.v2i2.526

Rublik, N. (2018). Chinese cultural beliefs: Implications for the Chinese learner of English. Sino-US English Teaching, 15(4), 173-184. https://doi.org/10.17265/ 1539-8072/2018.04.001

Salili, F. (1996). Accepting personal responsibility for learning. In D. A. Watkins \& J. B. Biggs (Eds.), The Chinese learner: Cultural, psychological and contextual influences (pp. 86-105). The Central Printing Press.

Valiente, C. (2008). Are students using the 'wrong style' of learning? A multicultural scrutiny for helping teachers to appreciate differences. Active Learning in Higher Education, 9(1), 73-91. https://doi.org/10.1177/ 1469787407086746

Wan, Z. H., Wong, S. L., \& Yung, B. H. W. (2011). Common interest, common visions? Chinese science teacher educators' views about the values of teaching nature of science to prospective science teachers. Science Education, 95(6), 1101-1123. https://doi.org/10.1002/sce.20451

Wang, C. C., Andre, K., \& Greenwood, K. M. (2015). Chinese students studying at Australian universities with specific reference to nursing students: A narrative literature review. Nurse Education Today, 35(4), 609-619. https://doi.org/10.1016/j.nedt.2014.12.005

Xing, M., Wang, J., \& Spencer, K. (2008). Raising students' awareness of crosscultural contrastive rhetoric via an e-learning course. Language Learning \& Technology, 12(2), 71-93. http://dx.doi.org/10125/44144

KEN CHAN received his $\mathrm{PhD}$ from the Department of Zoology at The University of Queensland (Australia) in 1993. He has since taught and researched in a number of universities in Australia and China, the latest being at Jinan University's Research Institute of Hydrobiology as a visiting professor. He has published extensively in pure science areas that include evolutionary biology, ecology, and zoology. His research interests now incorporate student behavior relating to learning biological sciences. Email: kin2pituri@yahoo.com.au 